\title{
PENGARUH MANAJEMEN MODAL KERJA TERHADAP PROFITABILITAS PADA PERUSAHAAN FARMASI YANG TERDAFTAR DI BEI
}

\author{
Mardiyana \\ Program Studi Akuntansi, Politeknik LP3I Medan \\ Mayang Murni \\ Program Studi Akuntansi, Politeknik LP3I Medan
}

*Corresponding author: E-mail: mardiyana604@gmail.com,

mayang.ashari@gmail.com

\begin{abstract}
Abstrak
Manajemen modal kerja adalah suatu aspek pengelolaan aktiva lancar dan hutang lancar yang diperlukan perusahaan untuk menjalankan kegiatan operasinya untuk meningkatkan profitabilitas perusahaan. Manajemen modal kerja yang digunakan dalam penelitian ini adalah perputaran kas, perputaran piutang dan perputaran persediaan. Tujuan penelitian ini adalah untuk mengetahui pengaruh manajemen modal kerja terhadap profitabilitas perusahaan. Penelitian ini dilakukan pada perusahaan Farmasi yang terdaftar di Bursa Efek Indonesia (BEI) periode 2012-2016. Penentuan jumlah sampel dalam penelitian ini menggunakan metode purposive sampling. Hasil penelitian menunjukkan bahwa uji secara Parsial diketahui perputaran kas dan perputaran piutang berpengaruh signifikan terhadap profitabilitas, sedangkan perputaran persediaan tidak berpengaruh signifikan terhadap profitabilitas pada perusahaan Farmasi. Sedangkan secara Simultan diketahui perputaran kas, perputaran piutang dan perputaran persediaan berpengaruh signifikan terhadap profitabilitas pada perusahaan Farmasi.
\end{abstract}

Kata Kunci : Perputaran Kas, Perputaran Piutang, Perputaran Persediaan, Profitabilitas.

\begin{abstract}
Working capital management is an aspect of the management of current assets and current liabilities that the company needs to run its operations to improve the profitability of the company. The working capital management used in this research is cash turnover, receivable turnover and inventory turnover. The purpose of this study is to determine the effect of working capital management on corporate profitability. This research was conducted at Pharmaceutical Company which listed in Indonesia Stock Exchange (BEI) period 2012-2016. Determination of the number of samples in this study using purposive sampling method. The results showed that the test partially known cash turnover and receivables turnaround significant effect on profitability, while inventory turnover has no significant effect on profitability in Pharmaceutical companies. While simultaneously known cash turnover, receivable turnover and inventory turnover have a significant effect on profitability in Pharmaceutical company.
\end{abstract}

Keywords : Cash Turnover, Receivable Turnover, Inventory Turnover, Profitability. 


\section{PENDAHULUAN}

Manajemen modal kerja adalah kegiatan yang mencakup manajemen atas aktiva lancar dan kewajiban jangka pendek yang digunakan untuk memaksimalkan nilai perusahaan dengan mengelola aktiva lancar sehingga tingkat pengembalian sama atau lebih besar dari biaya modal yang digunakan dan pengawasan terhadap arus dana dalam aktiva lancar tersebut. Efisiensi modal kerja adalah ketepatan cara dalam mengupayakan agar modal kerja yang tersedia dalam keadaan cukup. Dalam pengelolaan modal kerja elemen yang perlu diperhatikan ada tiga yaitu kas, piutang dan persediaan. Semakin cepat tingkat perputaran masing-masing elemen maka modal kerja dapat dikatakan efisien.

Menurut penelitian terdahulu, yang dilakukanoleh Utami dan Dewi (2016) berjudul "Pengaruh Manajemen Modal Kerja Terhadap Profitabilitas Perusahaan Manufaktur Yang Terdaftar Di Bursa Efek Indonesia" dari hasil penelitiannya dapat diketahui bahwa Perputaran kas, Perputaran piutang, Perputaran persediaan berpengaruh positif dan signifikan terhadap profitabilitas pada perusahaan manufaktur yang terdaftar di Bursa Efek Indonesia. Perbedaan penelitian ini dengan sebelumnya terletak pada sektor perusahaan yaitu sektor perusahaan dibidang Farmasi yang terdaftar di Bursa Efek Indonesia pada periode 2012-2016.

Berdasarkan laporan keuangan perusahaan farmasi yang terdaftar di BEI pada tahun 2012 sampai 2016 menunjukkan kesenjangan pada tahun 2013 perputaran kasnaik tetapi ROA turun. Pada tahun 2015 perputaran piutang mengalami kenaikan tetapi ROA mengalami penurunan. Sedangkan perputaran persediaan mengalami peningkatan pada tahun 2014 tetapi ROA justru mengalami penurunan. Berdasarkan uraian yang telah dipaparkan diatas, maka penelitian ini di beri judul "Pengaruh Manajemen Modal Kerja Terhadap Profitabilitas Pada Perusahaan Farmasi Yang Terdaftar Di Bursa Efek Indonesia".

Berdasarkan latar belakang masalah yang telah diuraikan diatas, maka permasalahan yang dapat dirumuskan dalam penelitian ini adalah Apakah perputaran kas, perputaran piutang, perputaran persediaan berpengaruh signifikan secara parsial dan simultan terhadap profitabilitas pada perusahaan sektor farmasi yang terdaftar di Bursa Efek Indonesia. Adapun tujuan dari penelitian ini adalah

Untuk mengetahui pengaruh perputaran kas, perputaran piutang, perputaran persediaan secara parsial dan simultan terhadap profitabilitas pada perusahaan sektor farmasi yang terdaftar di Bursa Efek Indonesia.

\section{Pengertian Rasio Profitabilitas}

Fahmi (2013 : 80) menyatakanrasio profitabilitas adalah rasio yang digunakan unutk mengukur efektivitas manajemen secara keseluruhan yang ditujukan oleh besar kecilnya tingkat keuntungan yang diperoleh dalam hubungannya dengan penjualan maupun investasi. 


\section{Jenis-Jenis Rasio Profitabilitas}

Fahmi (2013 : 80) menyatakan "Rasio profitabilitas secara umum ada empat (4) yang digunakan dalam menghitung profitabilitas perusahaan". Rasio-rasio tersebut antara lain :

a. Gross Profit Margin

Rasio Gross Profit Margin merupakan rasio yang memperlihatkan hubungan antara penjualan dan beban pokok penjualan.$$
G P M=\frac{\text { Sales-Cost of Good Sold }}{\text { Sales }}
$$ Sales}

b. Net Profit Margin

Rasio Net Profit Margin disebut juga dengan rasio pendapatan terhadap penjualan.

c. Return On Investment

$$
N P M=\frac{\text { Earning After Tax }}{\text { Sales }}
$$

Rasio Return On Investment(ROI) atau Return on Total Asset(ROA) merupakan rasio yang menunjukkan hasil (return) atas jumlah aktiva yang digunakan dalam perusahaan.

$$
\begin{gathered}
\text { ROI / ROA }=\frac{\text { Earning After Tax (EAT) }}{\text { Total Assets }} \\
\text { d. Return On Equity }(R O E)
\end{gathered}
$$

Rasio

Return On Equity (ROE) merupakan rasio untuk mengukur laba bersih sesudah pajak dengan modal sendiri.

$$
R O E=\frac{\text { Earning After Tax (EAT) }}{\text { Shareholder's Equity }}
$$

\section{Pengertian Manajemen Modal Kerja}

Monika

menyatakanmanajemen modal kerja (Working Capital Management) merupakan manajemen dari elemenelemen hutang lancar. Kebijakan modal kerja (Working Capital Policy) menunjukkan keputusan-keputusan mendasar mengenai target masing-masing elemen aktiva lancar dan bagaimana aktiva lancar tersebut dibelanjai.

\section{Pengertian Modal Kerja}

Syafitri dan wibowo (2016) menyatakan "Modal kerja merupakan investasi perusahaandalam bentuk aktiva lancar yang digunakan untuk membiayai operasional perusahaan dan yang nantinya harus diisi kembali sesuai dengan nominal yang telah ditetapkan".

\section{Pengelolaan Kas}

Fahmi (2013 : 109) menyatakan Manajemen kas yang efektif meliputi manajemen arus kas masuk dan keluar secara baik, yang terdiri dari: Menyinkronkan arus kas, menggunakan ambang atau (fload), mempercepat penerimaan, mendapatkan ketersediaan dana ke tempat yang membutuhkan dan mengendalikan pengeluaran.

Riyanto (2013 : 95) menyatakan "Perbandingan antara penjualan dengan jumlah kas rata-rata menggambarkan tingkat perputaran kas (cash turnover)". Makin tinggi turn over ini makin baik, karena ini berarti makin tinggi efisiensi penggunaan kasnya, Tetapi cash turnover yang berlebih-lebihan tingginya dapat berarti bahwa jumlah kas yang tersedia adalah terlalu kecil untuk volume sales yang bersangkutan. Adapun rumus untuk menghitung cash turnover adalah : 


\section{Cash Turnover $=\frac{\text { Net Sales }}{\text { Average Cash }}$}

\section{Pengelolaan Piutang}

Ismanto (2013)menyatakan

"piutang merupakan jumlah uang yang dipinjam dari perusahaan oleh pelanggan yang telah membeli barang atau memakai jasa secara kredit".

Riyanto (2013 : 90) menyatakan "Piutang sebagai elemen dari modal kerja selalu dalam keadaan berputar, periode perputaran atau periode terikatnya modal dalam piutang adalah tergantung kepada syarat pembayarannya". Makin lama syarat pembayaran, berarti makin lama modal terikat pada piutang, yang berarti bahwa tingkat perputarannya selama periode tertentu adalah makin rendah. Tingkat perputaran piutang (receivable turnover) dapat diketahui dengan membagi jumlah kredit penjualan selama periode tertentu dengan jumlah rata-rata piutang. Adapun rumus untuk menghitung receivale turnover adalah :

\section{Receivable Turnover}

$$
=\frac{\text { Net Credit Sales }}{\text { Average Receivables }}
$$

\section{Pengelolaan Persediaan}

Fahmi (2013 : 141)menyatakan Manajemen persediaan adalah kemampuan suatu perusahaan dalam mengatur dan mengelola setiap kebutuhan barang baik barang mentah, barang setengah jadi dan barang jadi agar selalu tersedia baik dalam kondisi pasar yang stabil dan berfluktuasi.
Riyanto (2013 : 73) menyatakan "Tingkat Perputaran Persediaan dapat diketahui dengan membagi jumlah harga pokok penjualan selama periode tertentu dengan jumlah rata-rata persediaan". Tinggi rendahnya inventory turnover mempunyai efek yang langsung terhadap besar kecilnya modal yang diinvestasikan dalam inventory. Makin tinggi turnovernya, berarti makin cepat perputarannya, yang berarti makin pendek waktu terikatnya modal dalam inventory. Adapun rumus untuk menghitung Inventory turnover adalah :

\section{Inventory Turnover $=\frac{\text { Cost ofgoods sold }}{\text { Average Inventory }}$}

\section{METODE PENELITIAN}

Penelitian ini dilaksanakan pada perusahaan Farmasi yang terdaftar di Bursa Efek Indonesia (BEI), dimulai pada bulan Desember 2017 sampai dengan bulan Maret 2018. Jenis data yang digunakan pada penelitian ini adalah data sekunder.Adapun sumber data yang digunakan dalam penelitian ini yaitu data internal dan data eksternal.Sedangkan metode pengumpulan data menggunakan metode dokumentasi dan metode studi pustaka. Populasi dalam penelitian adalah seluruh perusahaan Farmasi yang terdaftar di Bursa Efek Indonesia (BEI) periode 2012 sampai 2016. Teknik pengambilan sampel yang digunakan dalam penelitian adalah sampling purposive. Adapun kriteria penarikan sampel adalah: 
Tabel 1. Kriteria Penarikan Sampel Penelitian

\begin{tabular}{|l|l|c|}
\hline No & Kriteria & Sampel \\
\hline 1 & $\begin{array}{l}\text { Perusahaan Farmasi yang terdaftar di Bursa Efek Indonesia } \\
\text { (BEI) pada tahun 2012-2016. }\end{array}$ & 10 \\
\hline 2 & $\begin{array}{l}\text { Perusahaan Farmasi yang tidak menerbitkan laporan } \\
\text { tahunan secara berturut-turut selama tahun 2012-2016. }\end{array}$ & (6) \\
\hline & Total Sampel & 4 \\
\hline
\end{tabular}

Sumber : Data olahan penulis (2018)

Berikut ini adalah daftar perusahaan farmasi yang menjadi sampel penelitian: Tabel 2.Total Perusahaan Farmasi Yang Menjadi Sampel Penelitian

\begin{tabular}{|r|l|l|}
\hline No & Kode Perusahaan & Nama Perusahaan \\
\hline 1 & INAF & Indofarma Tbk \\
\hline 2 & KLBF & Kalbe Farma Tbk \\
\hline 4 & TSPC & $\begin{array}{l}\text { Taisho pharmaceutical indonesia } \\
\text { Tbk }\end{array}$ \\
\hline
\end{tabular}

Sumber : Data olahan penulis (2018)

Variabel yang diamati dalam penelitian ini adalah Return On Asset/ROA (Y), Perputaran Kas (X1),Perputaran Piutang $\left(\mathrm{X}_{2}\right)$, Perputaran Persediaan $\left(\mathrm{X}_{3}\right)$.

Data penelitian ini menggunakan analisis statistik deskriptif dan diuji dengan pengujian asumsi klasik yang terdiri dari uji normalitas, uji multikolinieritas, uji heteroskedastisitas, pengujian hipotesis menggunakan uji $\mathrm{t}$ (secara parsial) dan uji F (secara simultan). Sedangkan analisis data menggunakan analisis deskriptif kuantitatif dengan regresi linear berganda.
Model persamaan regresi linear berganda yaitu :

$$
Y=\alpha+\beta_{1} X_{1}+\beta_{2} X_{2}+\beta_{3} X_{3}+e
$$

Dimana:

$\alpha=$ Konstanta

$\beta_{1}=$ Koefisien regresi

$\mathrm{X}_{1}=$ Perputaran Kas

$\mathrm{X}_{2}=$ Perputaran Piutang

$\mathrm{X}_{3}=$ Perputaran Persediaan

$\mathrm{Y} \quad=$ Return On Asset 


\section{HASIL PENELITIAN}

Variabel penelitian ini adalah manajemen modal kerja yang terdiri dari Perputaran kas $\left(\mathrm{X}_{1}\right)$, Perputaran piutang $\left(\mathrm{X}_{2}\right)$, Perputaran persedian $\left(\mathrm{X}_{3}\right)$ dan profitabilitas / ROA (Y), yang digunakan untuk mengetahui pengaruh Perputaran kas(X1), Perputaran piutang(X2),
Perputaran persedian $\left(\mathrm{X}_{3}\right)$ dan profitabilitas / ROA(Y). Berikut adalah nilai rasio dari perputaran kas, perputaran piutang, perputaran persediaan dan Return On Assets (ROA) pada perusahaan Farmasi yang terdaftar di Bursa Efek Indonesia (BEI) pada tahun 2012-2016 yang digunakan dalam penelitian ini

Tabel 3.Nilai Rasio Data Penelitian

\begin{tabular}{|c|c|c|c|c|c|}
\hline KODE & TAHUN & CTO & RTO & ITO & ROA \\
\hline \multirow{5}{*}{ INAF } & 2012 & 5,93 & 9,67 & 4,88 & 3,57 \\
\hline & 2013 & $\begin{array}{l}11,0 \\
1\end{array}$ & 9,78 & 4,23 & 4,19 \\
\hline & 2014 & $\begin{array}{l}10,1 \\
8\end{array}$ & $\begin{array}{l}14,0 \\
6\end{array}$ & 4,94 & 0,09 \\
\hline & 2015 & 5,17 & $\begin{array}{l}16,5 \\
3\end{array}$ & 4,30 & 0,43 \\
\hline & 2016 & $\begin{array}{l}29,7 \\
8\end{array}$ & $\begin{array}{l}15,5 \\
7\end{array}$ & 4,58 & 1,26 \\
\hline \multirow{5}{*}{ KLBF } & 2012 & 7,33 & 7,55 & 3,36 & $\begin{array}{l}18,8 \\
5\end{array}$ \\
\hline & 2013 & $\begin{array}{l}11,2 \\
2\end{array}$ & 7,46 & 2,73 & $\begin{array}{l}17,4 \\
1\end{array}$ \\
\hline & 2014 & 9,17 & $\begin{array}{l}14,8 \\
0\end{array}$ & 2,88 & $\begin{array}{l}17,0 \\
7\end{array}$ \\
\hline & 2015 & 6,58 & $\begin{array}{l}15,1 \\
9\end{array}$ & 3,10 & $\begin{array}{l}15,0 \\
2\end{array}$ \\
\hline & 2016 & 6,69 & $\begin{array}{l}14,7 \\
3\end{array}$ & 2,96 & $\begin{array}{l}15,4 \\
4\end{array}$ \\
\hline \multirow{5}{*}{ SQBB } & 2012 & 2,26 & 8,18 & 4,37 & $\begin{array}{l}34,0 \\
6\end{array}$ \\
\hline & 2013 & 2,27 & 9,12 & 4,00 & $\begin{array}{l}35,5 \\
0\end{array}$ \\
\hline & 2014 & 2,58 & 8,51 & 4,66 & $\begin{array}{l}35,8 \\
8\end{array}$ \\
\hline & 2015 & 3,24 & 8,18 & 3,83 & $\begin{array}{l}32,3 \\
7\end{array}$ \\
\hline & 2016 & 3,43 & 7,93 & 4,36 & $\begin{array}{l}34,4 \\
7\end{array}$ \\
\hline
\end{tabular}


Sumber : Data olahan penulis (2018)

\begin{tabular}{|c|c|c|c|c|c|}
\hline \multirow{5}{*}{ TSPC } & 2012 & 4,02 & $\begin{array}{l}17,7 \\
8\end{array}$ & 5,42 & $\begin{array}{l}13,7 \\
1\end{array}$ \\
\hline & 2013 & 3,82 & $\begin{array}{l}16,9 \\
5 \\
\end{array}$ & 4,13 & $\begin{array}{l}11,8 \\
1\end{array}$ \\
\hline & 2014 & 5,14 & $\begin{array}{l}17,8 \\
9\end{array}$ & 4,33 & $\begin{array}{l}10,4 \\
5\end{array}$ \\
\hline & 2015 & 4,71 & $\begin{array}{l}17,7 \\
2\end{array}$ & 4,11 & 8,42 \\
\hline & 2016 & 5,42 & $\begin{array}{l}19,2 \\
1\end{array}$ & 4,15 & 8,28 \\
\hline
\end{tabular}

\section{Statistik Deskriptif}

Berikut ini adalah hasil dari analisis statistic deskriptif :

Tabel 4. Hasil Analisis Statistik Deskriptif

\begin{tabular}{|l|r|r|r|r|r|}
\hline & N & Minimum & Maximum & Mean & Std. Deviation \\
\hline Y & 20 &, 09 & 35,88 & 15,9140 & 12,35566 \\
X1 & 20 & 2,26 & 29,78 & 6,9975 & 6,04355 \\
X2 & 20 & 7,46 & 19,21 & 12,8405 & 4,24977 \\
X3 & 20 & 2,73 & 5,42 & 4,0660 &, 73005 \\
Valid N (listwise) & 20 & & & & \\
\hline
\end{tabular}

Sumber : Data olahan penulis (2018)

Berdasarkan hasil analisis statistik juga memenuhi standart statistic yang deskriptif diatas dapat dilihat nilai berhubungan dengan regresi linier Maximum, Minimum, Mean dan Standart berganda. Penelitian ini menggunakan uji Deviation.

\section{Uji Normalitas}

Uji normalitas dilakukan untuk mengetahui apakah data yang diolah berdistribusi secara normal atau tidak dan One Sample Kolmogorov-Smirnov dengan dasar pengambilan keputusan jika signifikan > 0,05 maka data berdistribusi normal. Berikut ini adalah hasil dari uji one sample kolmogorov- smirnov test:

Tabel 5. Hasil Uji One-Sample Kolmogorov-Smirnov Test

\begin{tabular}{|l|r|r|r|r|}
\hline & Y & X1 & X2 & X3 \\
\hline $\mathrm{N}$ & 20 & 20 & 20 & 20 \\
\hline
\end{tabular}




\begin{tabular}{|ll|r|r|r|r|} 
Normal Parameters & Mean & 15,9140 & 6,9975 & 12,8405 & 4,0660 \\
& Std. Deviation & 12,35566 & 6,04355 & 4,24977 &, 73005 \\
& Absolute &, 159 &, 228 &, 214 &, 174 \\
Most Extreme Differences & Positive &, 156 &, 228 &, 214 &, 107 \\
& Negative &,- 159 &,- 217 &,- 172 &,- 174 \\
& &, 709 & 1,020 &, 958 &, 778 \\
Kolmogorov-Smirnov Z & &, 696 &, 249 &, 317 &, 580 \\
Asymp. Sig. (2-tailed) & & & &
\end{tabular}

Sumber : Data olahan penulis (2018)

Hasil uji normalitas data pada tabel 5 diperoleh hasil sebagai berikut:

Angka signifikansi sebesar 0,249 untuk perputaran kas, angka signifikansi 0,317 untuk perputaran piutang, angka signifikansi sebesar 0,580 untuk perputaran persediaan dan angka signifikansi sebesar 0,696 untuk profitabilitas (ROA), Maka data penelitian berdistribusi normal.

\section{Uji Multikolinieritas}

Uji Multikolinieritas bertujuan untuk mengetahui apakah dalam model regresi ditemukan adanya korelasi antar variabel independen, untuk mengetahui adanya problem multikolinieritas maka dapat dilihat dari hasil colliniearity statistic yaitu nilai variance inflation factor (VIF) dan tolerance. Berikut ini adalah hasil dari uji multikolinearitas :

Tabel 6.Hasil dari Uji Multikolinearitas

\begin{tabular}{|c|c|c|c|c|c|c|c|}
\hline \multirow[t]{2}{*}{ Model } & \multicolumn{2}{|c|}{ Unstandardized Coefficients } & \multirow{2}{*}{$\begin{array}{c}\text { Standardized } \\
\text { Coefficients }\end{array}$} & \multirow[t]{2}{*}{$\mathrm{T}$} & \multirow[t]{2}{*}{ Sig. } & \multicolumn{2}{|c|}{ Collinearity Statistics } \\
\hline & B & Std. Error & & & & Tolerance & VIF \\
\hline (Constant) & 49,161 & 12,376 & & 3,972 & 001 & & \\
\hline $\mathrm{X} 1$ &,- 890 & ,337 &,- 435 & $-2,643$ & 018 & ,980 & 1,021 \\
\hline $\mathrm{X} 2$ & $-1,590$ & ,485 &,- 547 & $-3,278$ & ,005 & ,956 & 1,046 \\
\hline $\mathrm{X} 3$ & $-1,624$ & 2,800 &,- 096 &,- 580 &, 570 & ,971 & 1,029 \\
\hline
\end{tabular}

Sumber : Data olahan penulis (2018)

Berdasarkan Tabel 6 nilai tolerance masing-masing variabel bebas 
$>0,10$ dan VIF $<10$, sehingga dapat disimpulkan bahwa model regresi tidak mengandung gejala multikolinearitas.

\section{Uji Heteroskedastisitas}

Uji Heteroskedastisitas menguji terjadinya perbedaan variance residual suatu periode pengamatan ke periode pengamatan yang lain, cara memprediksi ada tidaknya heteroskedastisitas pada suatu model dapat dilihat dengan pola gambar scatterplot, regresi yang tidak terjadi heteroskedastisitas jika titik-titik data menyebar diatas dan dibawah atau disekitar angka 0 . Hasil uji heterokedastisitas diperoleh data scatterplot sebagai berikut :

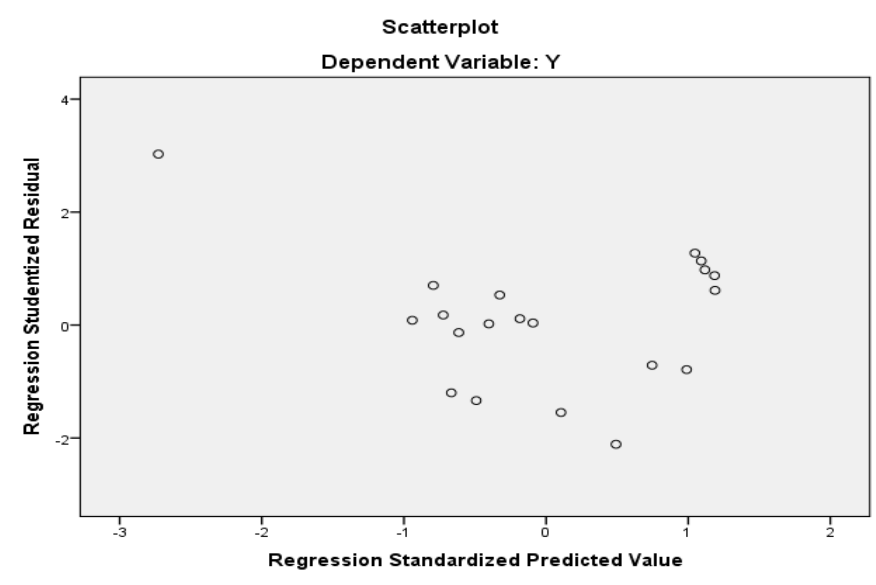

Gambar 1.Hasil Uji Heterokedastisitas

Gambar 1 memperlihatkan titiktitik menyebar dan tidak membentuk pola tertentu atau acak sehingga dapat disimpulkan bahwa tidak terjadi gejala heterokedastisitas pada data penelitian.

\section{Uji t (Secara Parsial)}

Uji t bertujuan untuk menunjukkan seberapa jauh pengaruh satu variabel dependen". Dengan melihat nilai Signifikan < 0,05 maka variabel bebas berpengaruh signifikan terhadap variabel terikat. Berikut adalah hasil dari uji $t$ :

Tabel 7. Hasil Uji t (Secara Parsial)

\begin{tabular}{|l|c|c|c|c|c|c|c|}
\hline Model & \multicolumn{2}{|c|}{$\begin{array}{c}\text { Unstandardize } \\
\text { d Coefficients }\end{array}$} & $\begin{array}{c}\text { Standardized } \\
\text { Coefficients }\end{array}$ & T & Sig. & \multicolumn{2}{|c|}{$\begin{array}{c}\text { Collinearity } \\
\text { Statistics }\end{array}$} \\
\cline { 2 - 4 } & B & $\begin{array}{c}\text { Std. } \\
\text { Error }\end{array}$ & Beta & & & $\begin{array}{c}\text { Toleranc } \\
\text { e }\end{array}$ & VIF \\
\hline
\end{tabular}




\begin{tabular}{|c|c|c|c|c|c|c|c|}
\hline $\begin{array}{l}\text { (Constant } \\
\text { ) }\end{array}$ & 49,161 & 12,376 & & 3,972 & $\begin{array}{r}00 \\
1\end{array}$ & & \\
\hline $\mathrm{X} 1$ & -,890 & 337, & -435 & $-2,643$ & $\begin{array}{r}, 01 \\
8\end{array}$ & 980 & $\begin{array}{r}1,02 \\
1\end{array}$ \\
\hline 1 & & & & & & & \\
\hline $\mathrm{X} 2$ & $-1,590$ & 485, & -547 & $-3,278$ & $\begin{array}{r}, 00 \\
5\end{array}$ & ,956 & $\begin{array}{r}1,04 \\
6\end{array}$ \\
\hline X3 & $-1,624$ & 2,800 & -096,- & -580 & $\begin{array}{r}57 \\
0\end{array}$ & ,971 & $\begin{array}{r}1,02 \\
9\end{array}$ \\
\hline
\end{tabular}

Sumber : Data olahan penulis (2018)

Hasil penelitian uji secara parsial sebagai berikut :

a. Perputaran kas mempunyai nilai sebesar -2,643 dengan nilai signifikan sebesar 0,018 . Berdasarkan hasil tersebut dapat dikatakan bahwa nilai signifikansi perputaran kas lebih kecil dari pada nilai taraf ujinya $(0,018<$ $0,05)$, maka perputaran kas $\left(\mathrm{X}_{1}\right)$ berpengaruh signifikan terhadap profitabilitas / ROA (Y).

b. Perputaran piutang mempunyai nilai sebesar $-3,278$ dengan nilai signifikan sebesar 0,005. Berdasarkan hasil tersebut dapat dikatakan bahwa nilai signifikansi perputaran piutang lebih kecil dari pada nilai taraf ujinya $(0,005<$ $0,05)$. maka perputaran piutang $\left(\mathrm{X}_{2}\right)$ berpengaruh signifikan terhadap profitabilitas / ROA (Y). c. Perputaran persediaan mempunyai nilai sebesar $-0,580$ dengan nilai signifikan sebesar 0,570 . Berdasarkan hasil tersebut dapat dikatakan bahwa nilai signifikansi perputaran persediaan lebih besar dari pada nilai taraf ujinya $(0,570>$ $0,05)$. maka perputaran persediaan $\left(\mathrm{X}_{3}\right)$ tidak berpengaruh terhadap profitabilitas / ROA (Y).

\section{Uji F (Secara Simultan)}

Uji $\mathrm{F}$ bertujuan untuk mengetahui apakah variabel bebas secara simultan mempunyai hubungan yang signifikan atau tidak terhadap variabel terikat". Dengan melihat nilai Signifikan $<0,05$ maka variabel independent (bebas) secara simultan berpengaruh terhadap variabel dependent (terikat). Berikut adalah hasil dari uji $F$ :

Tabel 8.Hasil Uji F (Secara Simultan)

\begin{tabular}{|l|r|r|r|c|c|}
\hline Model & Sum of Squares & Df & Mean Square & F & Sig. \\
\hline Regression & 1666,412 & 3 & 555,471 & 7,201 &, $003^{\mathrm{b}}$ \\
Residual & 1234,174 & 16 & 77,136 & & \\
\hline
\end{tabular}




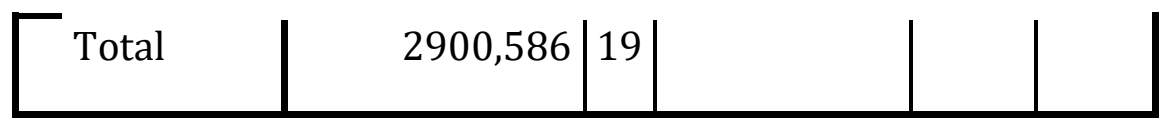

Sumber : Data olahan penulis (2018)

Berdasarkan hasil uji secara simultan dapat diketahui bahwa model persamaan ini memiliki tingkat signifikansi yaitu sebesar 0,003 lebih kecil dibanding nilai $\alpha 0,05$ dengan nilai $F$ sebesar 7,201, ini berarti secara simultan perputaran kas $\left(\mathrm{X}_{1}\right)$, perputaran piutang $\left(\mathrm{X}_{2}\right)$, perputaran persediaan $\left(\mathrm{X}_{3}\right)$ berpengaruh signifikan terhadap profitabilitas / ROA (Y). Sehingga perputaran kas $\left(\mathrm{X}_{1}\right)$, perputaran piutang $\left(\mathrm{X}_{2}\right)$ dan perputaran persediaan $\left(\mathrm{X}_{3}\right)$ berpengaruh signifikan terhadap profitabilitas / ROA (Y) sebesar 72,01\%.

\section{Pengaruh Manajemen Modal Kerja terhadap Profitabilitas}

Berdasarkan hasil penelitian secara simultan dapat diketahui bahwa manajemen modal kerja memiliki nilai signifikan sebesar 0,003 yang lebih kecil dari 0,05 , artinya dapat dikatakan bahwa manajemen modal kerja yang terdiri dari variabel perputaran kas $\left(\mathrm{X}_{1}\right)$, perputaran piutang $\left(\mathrm{X}_{2}\right)$, perputaran persediaan $\left(\mathrm{X}_{3}\right)$ secara simultan berpengaruh positif dan signifikan terhadap profitabilitas / ROA (Y). Hal ini didukung pula oleh penelitian yang dilakukan oleh Utami dan Dewi (2016) yang menyatakan bahwa manajemen modal kerja berpengaruh positif dan signifikan terhadap profitabilitas. Adanya pengaruh yang positif berarti bahwa semakin baik manajemen modal kerja maka akan semakin baik kinerja perusahaan dalam menghasilkan profitabilitas. Maka jika pengelolaan perputaran kas, perputaran piutang, perputaran persediaan dapat dilakukan lebih baik lagi maka perusahaan akan mengalami peningkatan pada tahun yang akan datang.

\section{Pengaruh Perputaran Kas terhadap Profitabilitas}

Berdasarkan hasil penelitian dapat diketahui bahwa nilai signifikan perputaran kas sebesar 0,019<0,05 berarti perputaran kas berpengaruh positif dan signifikan terhadap ROA. Hal ini didukung pula oleh penelitian yang dilakukan oleh Utami dan Dewi (2016) yang menyatakan bahwa tingkat perputaran kas berpengaruh positif dan signifikan terhadap profitabilitas. Adanya pengaruh yang positif berarti bahwa semakin tinggi perputaran kas maka keuntungan yang diperoleh perusahaan juga akan semakin tinggi dengan jumlah kas tertentu yang dimiliki perusahaan dan akan menghasilkan penjualan yang tinggi.

\section{Pengaruh Perputaran Piutang terhadap Profitabilitas}

Berdasarkan hasil penelitian dapat diketahui bahwa nilai signifikansi perputaran piutang sebesar 0,005 $<0,05$ berarti perputaran piutang berpengaruh positif dan signifikan terhadap ROA. Hal ini didukung pula oleh penelitian yang dilakukan oleh Utami dan Dewi (2016) yang menyatakan bahwa tingkat perputaran piutang berpengaruh positif 
dan signifikan terhadap profitabilitas. Adanya pengaruh yang positif berarti bahwa semakin tinggi perputaran piutang maka modal yang diinvestasikan pada piutang akan semakin sedikit, yang berarti bahwa peningkatan penjualan rendah yang diikuti oleh penerimaan kas, dimana kondisi kesehatan kas digunakan sebagai acuan profitabilitas perusahaan.

\section{Pengaruh Perputaran Persediaan terhadap Profitabilitas}

Berdasarkan hasil penelitian dapat diketahui bahwa nilai signifikan perputaran persediaan sebesar 0,563 > 0,05 berarti perputaran persediaan tidak berpengaruh terhadap ROA. Hal ini didukung pula oleh penelitian yang dilakukan oleh Safitri dan Utami (2017) yang menyatakan bahwa tingkat perputaran persediaan tidak berpengaruh terhadap profitabilitas. Hal ini dikarenakan perputaran persediaan tidak berpengaruh terhadap profitabilitas, disebabkan oleh banyaknya persediaan barang dagang yang menumpuk digudang karena lambannya penjualan persediaan.

\section{KESIMPULAN}

Berdasarkan hasil analisis data dan pembahasan yang telah dilakukan maka dapat ditarik kesimpulan, bahwa perhitungan uji secara simultan diketahui variabel bebas yaitu perputaran kas ( $\left.\mathrm{X}_{1}\right)$, perputaran piutang $\left(\mathrm{X}_{2}\right)$ dan perputaran persediaan $\left(\mathrm{X}_{3}\right)$ berpengaruh signifikan terhadap profitabilitas / ROA (Y) pada perusahaan Farmasi. Sedangkan perhitungan uji secara parsial diketahui perputaran kas $\left(\mathrm{X}_{1}\right)$ dan perputaran piutang $\left(\mathrm{X}_{2}\right)$ berpengaruh signifikan terhadap profitabilitas / ROA (Y) dan perputaran persediaan $\left(\mathrm{X}_{3}\right)$ tidak berpengaruh signifikan terhadap profitabilitas / ROA (Y) pada perusahaan Farmasi.

\section{Daftar Pustaka}

F, I. (2013). Pe ngantar Manajemen Keuangan, Cetakan Kedua, Bandung : Alfabeta.

H, T. dan Saifi (2014). Analisis Manajemen Piutang dalam Meningkatkan Volume Penjualan Studi Kasus PT. Varia Usaha Beton, Waru-Sidoarjo Periode 2013). Jurnal Administrasi Bisnis (JAB), Vol.16 No.1, November 2014.

I. (2013). Pengaruh Manajemen Modal Kerja Terhadap Profitabilitas Studi Kasus pada Pengusaha Keramik di Sentra Kerajinan Keramik di Banjarnegara. Skripsi. Jurusan Manajemen Universitas Negeri Semarang.

K. (2015). Analisis Laporan Keuangan, Cetakan Kedelapan, Jakarta : PT.RajaGrafindo Persada.

L. (2017). Pengaruh Perturan Kas, Perputaran Persediaan dan Perputaran Piutang Terhadap Profitabilitas pada Perusahaan Manufaktur yang Terdaftar di Bursa Efek Indonesia. Skripsi. Jurusan Pendidikan Akuntansi Universitas Negeri Yogyakarta. 
M. (2017). Pengaruh Manajemen Modal Kerja Terhadap Profitabilitas pada Perusahaan Keramik Porselin dan Kaca Listing di Bursa Efek Indonesia Periode 2009-2014. JOM FISIP, Vol.4 No.2, Oktober 2017.

R, H. (2013). Pengaruh Strategi Bisnis Terhadap Hubungan Manajemen Persediaan Dan Kinerja Perusahaan Studi Pada Perusahaan Publik Di BEI. Jurnal Ekonomi Dan Bisnis, Vol.12, No.1, Juni 2013.

R, B. (2013). Dasar Dasar Pembelanjaan Perusahaan, Cetakan Ketigabelas, Yogyakarta : BPFE-yogyakarta.

S. (2014). Aplikasi Statistika Untuk Penelitian, Cetakan Pertama, Jakarta : Lentera Ilmu Cendekia.

S. (2016). Metode Penelitian Kuantitatif, Kualitatif, dan R\&D, Cetakan Kesembilanbelas, Bandung : Alfabeta, CV.

S. (2014). Metodologi Penelitian, Cetakan Pertama, Yogyakarta : pustakabarupress. 